\title{
Pisać w trzecim języku: przestrzeń między świętym a świeckim w myśli Gershoma Scholema i Jacques'a Derridy
}

Karen Underhill

TEKSTY DRUGIE 2016, NR 5, S. 198-216

DOI: $10.18318 /$ td.2016.5.14

Czyż teologia negatywna - powiedzieliśmy już dość na ten temat - nie jest też najbardziej wydajną formalizacją? Największą mocą tego, co możliwe? Rezerwą języka, tak oszczędną w słowach, a niemal niewyczerpaną? Ta literatura wiecznie eliptyczna, małomówna, kryptyczna, uparcie wycofująca się wszakże z wszelkiej literatury, niedostępna nawet tam, dokąd zdaje się zmierzać, przesycona irytacją zazdrość, którą pasja wyprowadza poza samą siebie. [...] Utrzymuje ona pragnienie w zawieszeniu i - zawsze mówiąc zbyt wiele lub zbyt mało za każdym razem was opuszcza, zarazem nigdy od was nie odchodząc.

$$
\text { Jacques Derrida Saufle nom }{ }^{1}
$$

Czym miałby w ogóle być ten język? Trzeci język, który wydobywa z siebie przeciwieństwa sakralny/niesakralny, święty/nieświęty?

Jacques Derrida Oczyjęzyka ${ }^{2}$

1 J. Derrida Saufle nom, w: tegoż On the Name, trans. T. Dutoit, Stanford University Press, Stanford 1995, s. 85.

2 J. Derrida Oczy języka, przeł. T. Swoboda, "Literatura na Świecie"2011 nr 5/6, s. 341 .
Karen Underhill adiunkt na wydziale Literatury i Języków Słowiańskich i Bałtyckich na Uniwersytecie Illinois w Chicago. Zajmuje się kulturą polską i żydowską, zwłaszcza modernizmem, twórczością Brunona Schulza i narracjami o Polsce jako przestrzeni wielokulturowej. Publikowała w „POLIN”, "East European Politics and Societies", „Slavic \& East European Journal", „Ruchu Literackim”, "Jewish Renaissance" i „Czasie Kultury”. Obecnie pracuje nad książką Writing in the Third Language: Bruno Schulz and Jewish Modernity. 
$\mathbf{W}$ niniejszych rozważaniach odwołuję się do metafory palimpsestu, by podjać pytanie, jakie Jacques Derrida stawia w eseju Oczyjęzyka: czym byłby ów trzeci język, który wydobywa z siebie przeciwieństwo sakralny/ niesakralny? Esej Derridy to szczegółowe, krytyczne odczytanie listu, który Gershom Scholem skierował w roku 1926 do Franza Rosenzweiga, a który był poświęcony „sekularyzacji” czy „aktualizacji” języka hebrajskiego, czyli procesowi, jaki toczył się wówczas w Palestynie. W liście tym, pisanym w tonacji apokaliptycznej, Scholem przyjmuje teologiczną przesłankę, wedle której hebrajszczyzna jest językiem świętym, i przestrzega przed sądem bożym, jaki spaść może na tych, którzy poważyli się przeobrazić świętą mowę w narzędzie codziennej komunikacji. „Ci, co ponownie powołali do życia hebrajszczyznę, nie wierzyli w sąd, jaki tym samym sprowadzili na nasze głowy. [...] Dzień w dzień przywoływaliśmy dawne imiona, a teraz nie jesteśmy już w stanie oddalić potencji, które w nich tkwią"3.

Analizując ten idiosynkratyczny list, Derrida kwestionuje samą możliwość tego rodzaju pęknięcia w języku, pęknięcia między tym, co święte, a tym, co świeckie. Jego dekonstrukcja listu Scholema wiąże się z odrzuceniem neoromantycznej przesłanki, która głosi nie tyle, że istnieje święta, „otchłanna istota [...] języka"4, czyli że potencjalną ważność zachowuje kategoria bożego Imienia, ile że istnieje święty język odrębny od świeckich, mówionych języków komunikacji; że istnieje jakikolwiek język mówiony, który nie jest „nawiedzany" przez „imiona”.

W swoim eseju Derrida wprowadza ideę „trzeciego języka” - pozycji usytuowanej gdzieś między czy poza językiem świętym i świeckim - w trybie eksperymentu myślowego, po to jednak, by zaraz odrzucić taką figurę jako logicznie niemożliwą. Wszelako jego opis tego, czym taki trzeci język musiałby być - a mianowicie pewnym „doświadczeniem języka” naznaczonym przestrogą, swego rodzaju profetyczną mową pośrednika - jest przecież nader pociągający. Derrida pisze:

Można by się tu pokusić o coś, co pozwolę sobie nazwać hipotezą trzeciego języka. [...] Wyrażenie trzeci język oznacza raczej element różnicowany i różnicujący, pewne medium, które nie jest sensu stricto językowe, lecz staje się miejscem doświadczania języka, który nie jest ani święty, ani świecki,

3 G. Scholem Wyznanie o naszym języku, przeł. K. Rapacki, „Literatura na Świecie” 2011 nr 5/6, s. 330-331.

4 J. Derrida Oczyjęzyka, s. 343. 
lecz umożliwia przechodzenie od jednego do drugiego, tłumaczenie jednego drugim, sięganie z jego do drugiego. Innymi słowy, logika tej hipotezy [...] nakazywałaby właśnie założyć, że nadawca i adresat sytuują się między oboma językami i że pierwszy - ten, który ostrzega - przedstawia się jako pośrednik, tłumacz, mediator. Uczestnicząc w obu językach, mówi nimi tylko gdzieś z tego trzeciego, a w każdym razie z jakiegoś rejonu owego języka, który nie jest jeszcze czy też już święty lub świecki, albo też jest już, jeszcze, oboma naraz i pozwala uczynić ów krok na brzegu otchłani. ${ }^{5}$

Argumentując - jak się zdaje - przeciw możliwości istnienia tego rodzaju trzeciego języka czy raczej dowodząc fałszywości samej dychotomii święte/świeckie, w swoim eseju Derrida inicjuje zarazem dokładnie takie właśnie „doświadczenie” lingwistyczne: otwiera przestrzeń dyskursywną, gdzie sakralny potencjał, „otchłanna istota języka” jest ewokowana, przywoływana na nowo, poddawana refleksji - gdzie nie pozwala jej się pogrążyć w zapomnieniu. Tę pracę wykonuje też jednak list Gershoma Scholema ten sam list, który wedle Derridy cechuje „święte szaleństwo”, „lękliwe wyczekiwanie, pragnienie i przerażenie wobec możliwości niemożliwego, czyli wobec słowa, ni mniej, ni więcej, jak tylko odpowiedzi Boga decydującego się przemówić"6.

Proponuję zatem posłużyć się Derridiańską kategorią „trzeciego języka” na określenie tego właśnie sposobu pisania, który zarówno Scholem, jak i podążający za nim Derrida uprawiają w swoich tekstach. Oba teksty stanowią próbę rozwinięcia i podtrzymania w istnieniu "trzeciego języka” - tj. dyskursu, który nie tylko „wydobywa z siebie przeciwieństwa sakralny/niesakralny, święty/nieświęty", lecz także ma na uwadze ewokację tego przeciwieństwa oraz otwarcie przestrzeni pojęciowej i uruchomienie interakcji - w ramach parametrów samego tekstu i na czas jego trwania - między świętym a nieświętym. W istocie teksty Scholema i Derridy mówią o języku jako o pewnego rodzaju palimpseście: jego powierzchnia czy też widoczna, czytelna warstwa składa się z (nieświętego) języka codziennej komunikacji; jego wymazana, wyparta czy też widmowa warstwa pierwotna to otchłań potencjalności, ,otchłanna istota języka", ponad którą zawieszona jest mowa codzienna; jej widmowe ślady, podobne śladom wyłaniającym się w palimpsestowym Piśmie, "nawiedzają" nasz codzienny język. Jak ujmuje to Scholem w złowróżbnych

5 Tamże, s. 341.

6 Tamże, s. 357. 
słowach: „W tym języku żyjemy wszak nad otchłanią i niemal wszyscy poruszamy się z pewnością ślepców. [...] Otchłań milczała, oni zaś ją - dawne imiona i pieczęcie - przekazali młodzieży. [...] W naszych wypowiedziach imiona błąkają się niczym duchy"7. Derrida zaś komentuje:

Język musi poddać się temu powierzchniowemu efektowi, efektowi na powierzchni, ale efektowi, który polega na tworzeniu powierzchni, płaskiego terenu, po powierzchni którego kroczy lunatyk. Kroczymy po powierzchni, lunatykujemy jednak tylko dlatego, że wierzymy, iż kroczymy po powierzchni: wierzymy w powierzchnię. Prawdę mówiąc - a prawda ta nie należy już do porządku obiektywności czy też wiedzy przekazywanej przez świecki język powierzchni - powierzchnia nie istnieje. Jest tylko otchłań. Święty język to otchłań. ${ }^{8}$

Teksty Scholema i Derridy możemy określić mianem „palimpsestowych” (palimpsestuous) ${ }^{9} \mathrm{w}$ tym sensie, że opierają się one na negocjacji stosunku między dwiema warstwami języka, między świętymi i nieświętymi aspektami języka, i że wciagają swoich czytelników w owe negocjacje, wywołując dreszcz nadziei lub niepokoju, sugestię sakralnego potencjału uśpionego w języku. Najważniejsze pytanie, które wymaga namysłu, brzmi chyba: na czym polega ów „sakralny” potencjał? Bez względu na dramatyczne różnice między ideologicznymi i filozoficznymi przesłankami leżącymi u podłoża tych dwóch tekstów zarówno dla Scholema, jak i dla Derridy celem tego przedsięwzięcia i faktycznym rezultatem owej „palimpsestyzacji” języka jest wytworzenie przestrzeni etycznego zaangażowania ze strony krytyka,

7 G. Scholem Wyznanie o naszym języku, s. 330-331.

8 J. Derrida Oczy języka, s. 343.

Według Sary Dillon termin palimpsestuous „po raz pierwszy pojawił się w druku w języku francuskim, w książce Palimpsesty Gerarda Genette'a (1982)", gdzie z kolei ideę "lektury palimpsestowej" przypisuje się Phillipe'owi Lejeune. W swojej rozprawie zatytułowanej The Palipsest Dillon podejmuje się, jak pisze, „szczegółowej teoretyzacji neologizmu palimpsestuous. [...] Według The Oxford English Dictionary, oficjalnym przymiotnikiem od słowa palimpsest jest palimpsestic, który oznacza coś, co «jest palimpsestem lub go wytwarza». Tymczasem palimpsestuous nie oznacza cechy bycia palimpsestem - lub czymś, co palimpsest generuje - lecz ów typ relacyjności, który urzeczywistnia się $w$ ramach palimpsestu. O ile zatem palimpsestic odnosi się do procesu uwarstwienia, który wytwarza palimpsest, palimpsestuous opisuje strukturę, z którą zostajemy skonfrontowani w wyniku tego procesu, a także następujący potem proces ponownego wyłaniania się ukrytego pisma". S. Dillon The Palimpsest, Continuum, London-New York 2007, s. 4. 
czytelnika, a w istocie każdej jednostki żyjącej w obrębie mowy. Idzie zatem o wzbogacenie języka, o przywrócenie mu etycznego ładunku. „Eliptyczna, [...] kryptyczna, uparcie wycofująca się", jak pisze Derrida o literaturze teologii negatywnej w Saufle nom, ta odmiana dyskursu o języku wydaje się zmierzać właśnie do tego, by „utrzymywać pragnienie w zawieszeniu” - by niejako przeszmuglować mesjańskie przeczucia do epoki postteologicznej ${ }^{10}$.

Jak wyglądałby tekst pisany w „trzecim języku”? Jak by brzmiał? Poruszający tekst Scholema, zatytułowany Wyznanie o naszym języku, to list otwarty do Rosenzweiga, napisany w roku 1926 z okazji czterdziestych urodzin adresata i pomyślany jako wkład do tomu esejów na jego cześć. Scholem, uważany za twórcę współczesnych, akademickich badań nad kabałą, był zagorzałym syjonistą: w roku 1923 przeniósł się do Palestyny, gdzie dziesięć lat później miał zostać pierwszym profesorem mistycyzmu żydowskiego na Uniwersytecie Hebrajskim. Rosenzweig natomiast był zajadłym antysyjonistą: postrzegał syjonizm jako „świecką formę mesjanizmu”, jako ruch, który podejmuje próbę "«znormalizowania», a więc także «zeświecczenia» judaizmu"11. Ten szczególny kontekst listu Scholema do Rosenzweiga jest istotny dla zrozumienia tonacji, w jakiej tekst ów jest utrzymany. Scholem określił swój list mianem „wyznania”: za jego pośrednictwem starał się w pewnym sensie pojednać z Rosenzweigiem w kwestii, która ich poróżniła - możliwości odrodzenia ducha żydowskiego w epoce współczesnej, jakie miałoby się dokonać dzięki syjonizmowi. Tekst został napisany po niemiecku - w pierwszym języku obu myślicieli - dotyczył zaś odrodzenia języka hebrajskiego w Palestynie: czegoś, co w swoim liście Scholem określa mianem „sekularyzacji” czy „aktualizacji" hebrajszczyzny. Poniższy fragment pozwala uchwycić zarówno rdzeń Scholemowego wywodu, jak i dominującą w tym liście tonację apokaliptycznego lęku oraz pragnienia:

Ten kraj to wulkan. [...] Bardziej niepokojące [...] jest jednak inne niebezpieczeństwo, wywołane nieuchronnie przez syjonistyczne przedsięwzięcie: jak to jest z „aktualizacją” hebrajszczyzny? Czyż otchłań świętego języka, który wpajany jest naszym dzieciom, nie musi ponownie się rozewrzeć? Oczywiście, ludzie tutaj nie wiedzą, co czynią. Sądzą, że zeświecczyli język, że wyrwali mu apokaliptyczne żądło. A przecież to nieprawda, wszak zeświecczenie języka to tylko frazes, façon de parler. Po prostu nie

10 J. Derrida Saufle nom, s. 85.

11 J. Derrida Oczy języka, s. 335. 
sposób opróżnić słów wypełnionych po brzegi, chyba że za cenę samego języka. [...] W tym języku żyjemy wszak nad otchłanią i niemal wszyscy poruszamy się z pewnością ślepców. Lecz gdy przejrzymy na oczy - my lub ci, którzy przyjdą po nas - czyż nie stoczymy się w dół?²

Scholem kończy zaś ostrzeżeniem:

Język to imię. W imieniu zamknięta jest potęga języka, opieczętowana jest jego otchłań. Dzień w dzień przywoływaliśmy dawne imiona, a teraz nie jesteśmy już w stanie oddalić potencji, które w nich tkwią. [...] Ci, co ponownie powołali do życia hebrajszczyznę, nie wierzyli w sąd, jaki tym samym sprowadzili na nasze głowy. Oby lekkomyślność, która prowadzi nas tą apokaliptyczną ścieżką, nie przywiodła nas do zguby. ${ }^{13}$

Język i styl listu Scholema do Rosenzweiga dramatycznie różnią się od stylistyki, w jakiej utrzymane są jego naukowe prace poświęcone żydowskiemu mistycyzmowi. Twierdzenia i przestrogi Scholema są poniekąd groteskowe. Brzmią tak, jakby miały odtwarzać profetyczny czy liturgiczny sposób pisania lub mówienia; jakby w pewnym konkretnym momencie historycznym miały odgrywać kabalistyczne koncepcje dotyczące sakralnej mocy bożego Imienia, które Scholem omawia szczegółowo w innych pismach. Natychmiast narzuca się więc pytanie, które stawia Derrida: Cóż takiego Scholem może mieć na myśli, wygłaszając tego rodzaju twierdzenia? Możemy też zapytać: co jego tekst może robić - prócz tego, że coś znaczy? Sądzę, że tam, gdzie jego tekst nabiera charakteru palimpsestu, zaczyna też pragnąć czegoś więcej niż komunikacji: zaczyna - właśnie - generować pragnienie. Wpisuje się wówczas w obręb przedsięwzięcia zwanego teologią negatywną, przeradzając się w „przesyconą irytacją zazdrość, którą pasja wyprowadza poza samą siebie. [...] Utrzymuje pragnienie w zawieszeniu"14.

W swoim odczytaniu Derrida podchodzi jednak zrazu do listu Scholema tak, jakby tekst ów nie przynależał do literatury profetycznej, jakby nie był dziełem przenikniętym zazdrosną nostalgią za możliwością proroctwa, lecz jak gdyby był to tekst filozoficzny. Choć Derrida twierdzi, że podejmuje

G. Scholem Wyznanie o naszym języku, s. 329-330.

13 Tamże, s. 330-331.

14 J. Derrida Saufle nom, s. 85. 
coś, co nazywa „jak najbardziej wewnątrztekstową” lekturą listu Scholema, nader błyskotliwie wprowadza do swojego odczytania logikę dekonstrukcji pochodzącą z zewnątrz tego tekstu ${ }^{15}$. Pisze zatem: „Wydaje się, że w logice tej argumentacji - logice szalonej z punktu widzenia każdej filozofii - Scholem mówi o rzeczach niemożliwych do pogodzenia, wzajemnie się znoszących"16. A przecież list Scholema, zwłaszcza jeśli ulokować go w kontekście klimatu intelektualnego nowoczesnego mesjanizmu żydowskiego, można odczytać zgodnie z inną logiką: logiką tekstu mistycznego, który odwołuje się do symbolicznego obrazowania i języka. Można przyjąć, że tekst ten bezpośrednio usiłuje odtworzyć mistyczny sposób pisania w duchu kabalistycznych tekstów poświęconych naturze języka. Jego szaleństwo staje się jego zasadniczym tropem - strategią generowania „trzeciego języka"17.

Odwołując się do języka biblijnego, dotykając granic mowy modlitewnej czy prorockiej, a także przyjmując niemożliwe czy nielogiczne przesłanki, które wyraźnie odróżniają go od pisarstwa naukowego czy krytyczno-literackiego, tekst Scholema próbuje oddalić się od czegoś, co Walter Benjamin określał mianem „mieszczańskiej koncepcji języka”18, od języka pojętego jako narzędzie komunikacji. Zarazem stara się nawiązać kontakt z żywiołem symbolicznym, który cechuje mistyczne koncepcje języka, a także wywołać rezonans czy echo żywiołu tradycyjnego. Jak pisze Scholem w eseju o kabalistycznej teorii języka (1970):

15

Pisząc o muzyce, Theodor Adorno odnosi się do tej tęsknoty za językiem mesjańskim w epoce postteologicznej. „)ęzyk muzyki", czytamy w eseju Muzyka i język (1956), „jest całkiem odmienny od języka intencjonalnego. Zawiera wymiar teologiczny. To, co ma do powiedzenia, zostaje równocześnie objawione i zakryte. Jego Ideą jest boże Imię, któremu nadano pewną postać. To zdemitologizowana modlitwa, wyzbyta magicznej skuteczności. To człowiecza próba, jak zawsze skazana na porażkę, by wypowiedzieć Imię, nie zaś przekazywać jakieś znaczenia. [...] Muzyka odsyła do języka prawdziwego o tyle, że treść jest w niej tylko pozorem, czyni to jednak za cenę jednoznaczności, za cenę wyraźnego znaczenia, które przeniosło się do języków intencjonalnych". T.W. Adorno Quasi una Fantasia: Essays on Modern Music, Verso, London 1992, s. 2-3. Choć Adorno wskazuje tutaj, że muzyka może z istoty swojej zająć miejsce między świeckim światem komunikacji a mistyczną koncepcją świętego języka, czyli Imienia bożego, właśnie dlatego, że nie jest językiem słów, dotyka tu wielu cech, do których aspirują teksty takie jak list Scholema.

18 W. Benjamin O języku w ogóle i o języku człowieka, przeł. A. Lipszyc, w: tegoż Konstelacje, przeł. A. Lipszyc, A. Wołkowicz, Wydawnictwo UJ, Kraków 2012, s. 4. 
Punktem wyjścia wszystkich mistycznych teorii języka, do których należy zaliczyć także teorie kabalistów, jest przekonanie, że język - jako medium, w którym urzeczywistnia się i spełnia duchowe życie człowieka - zawiera pewną wewnętrzną jakość [...], pewną godność [...], coś związanego z jego struktura, co nie jest dostosowane do komunikacji tego, co komunikowalne, lecz (a wszelka symbolika opiera się na tym paradoksie) do komunikacji tego, co niekomunikowalne, czegoś, co żyje w nim w sposób niewyrażalny, a gdyby nawet mogło zostać wyrażone, nie miałoby wcale żadnego znaczenia, ani żadnego komunikowalnego „sensu”. Przekonanie to jest wspólną podstawą, a zarazem doświadczeniem, którym koncepcje te karmiły się, odradzając się w każdym pokoleniu, z naszym włącznie. ${ }^{19}$

Wspominając o odrodzeniu symbolicznych i mistycznych form literatury w jego własnym pokoleniu, Scholem odnosi się z pewnością - między innymi - do dzieł Franza Kafki i Waltera Benjamina, w szczególności zaś do mistycznych pism Benjamina poświęconych naturze języka i objawienia, takich jak O języku w ogóle i o języku człowieka (1916), Zadanie tłumacza (1923) czy tezy O pojęciu historii (1940), prac bezpośrednio inspirowanych przyjaźnią i wieloletnią korespondencją z Scholemem ${ }^{20}$. Sądzę zatem, że list Scholema do Rosenzweiga stanowi świadomą próbę przyjęcia podobnego tonu. W tym sensie ów eksperyment, jakim jest pisanie w trzecim języku, polega na zerwaniu z alibi stylistyki akademickiej i podjęciu próby spulchnienia powierzchni, komunikacyjnej warstwy języka, tak by jego otchłanna istota mogła raz po raz dochodzić do głosu, „rozbłyskiwać poprzez szczeliny” nowoczesnego dyskursu filozofii i historiografii ${ }^{21}$. Pisarz lub czytelnik, który posługuje się językiem w ten sposób, zestraja się z widmowymi śladami wymazanego tekstu, które przeświecają przez warstwę powierzchniową.

Pisanie w trzecim języku nie zmierza wcale do wytworzenia współczesnego tekstu „świętego". Stanowi raczej nieustanną próbę wskazania pewnej trudno uchwytnej granicy - tej samej, którą (pisząc o własnych badaniach nad kabałą) określił Scholem mianem „cienkiej granicy między

19 G. Scholem The Name of God and the Linguistic Theory of the Kabbalah (I), "Diogenes" Autumn 197279 , s. 60.

Zob. W. Benjamin Konstelacje, s. 1-18, 23-36, 311-323. 
religią a nihlizmem"22. Jak widzimy z kolei w jego liście do Rosenzweiga, takie pisanie można również postrzegać jako próbę stworzenia języka, który trwa na skraju otchłani czy też po prostu jest tym skrajem otchłani - próbę zachowania miejsca na dyskurs czy impuls teologiczny pod nieobecność sacrum.

Wiele lat później, w artykule poświęconym Imieniu Boga i kabalistycznej teorii języka, Scholem zaprezentował bezpośrednie, osobiste sformułowanie tego problemu, które można potraktować także jako wyzwanie. W eseju tym omawia on historyczne korzenie idei Imienia bożego - bądź Imion bożych - która rozwinęła się w żydowskiej literaturze mistycznej, analizuje też sposób, w jaki kategoria ta funkcjonuje w kabale. Jednakże na ostatnich stronach tego obszernego studium Scholem zmienia ton i, porzucając tryb naukowego opisu pewnego systemu teologicznego, zwraca się bezpośrednio do swoich współczesnych czytelników. Analiza kategorii Imienia bożego staje się dlań punktem wyjścia do rozważań o kryzysie, który charakteryzuje jego własne pokolenie. Passus ów stanowi także przykład tego, w jaki sposób Scholem mówi o sprawach, do których odnosił się w liście do Rosenzweiga, gdy nie eksperymentuje z językiem apokaliptycznym czy sakralnym. Przykład ten - mocą kontrastu - uwypukla silnie performatywny charakter tamtego listu.

To, co odczytujemy ze stworzenia i z objawienia, słowo boże, podatne jest na nieskończoną interpretację i odzwierciedla się w naszym języku. Jego promieniowanie czy brzmienie, które udaje nam się pochwycić, to nie tyle komunikacja, ile wezwanie. Tym, co obdarzone jest znaczeniem - sensem i formą - nie jest samo słowo, lecz tradycja tego słowa, jego zapośredniczenie i odbicie w czasie. Owa tradycja, która posiada własną dialektykę, ulega przemianom i potrafi przeobrazić się w cichy, ledwie słyszalny szept. Mogą też istnieć czasy, takie jak nasze własne, gdy nie sposób już jej przekazać dalej i gdy tradycja ta milknie. Oto jest właśnie ów wielki kryzys języka, który stał się naszym udziałem. Dziś nie potrafimy już pochwycić ostatniego skrawka tej tajemnicy, która niegdyś się w nim kryła. Zdaniem kabalistów to, że językiem można mówić, zawdzięczamy Imieniu, które jest w nim obecne. ${ }^{23}$

22 Tamże. 
W tym właśnie miejscu Scholem ponownie wprowadza do swoich analiz języka aspekt etyczny, ujęty w formie wezwania czy apelu:

Jaka będzie godność języka, z którego Bóg się wycofał? - to pytanie postawić muszą sobie ci, którzy sądzą, że w immanencji świata wciąż słyszą echo zaginionego słowa stworzenia. ${ }^{24}$

Jak się zdaje, Scholem pyta: „co robić?” - bądź też stara się nakłonić swoich współczesnych, by zadali sobie to pytanie. Bóg, to co święte - jako prawda, autentyczność czy znaczenie, wartości przyobiecane przez język - jest w odwrocie. Jak mamy się go trzymać, jak trzymać się skrawków jego Imienia i wymogów, które owo Imię nakłada na nas w formie przymierza? A jeśli do samego Imienia nie mamy już dostępu, winniśmy może postawić na jego performatywne odtworzenie w ramach rytuału przekazanego nam przez tradycję? Jeśli zaś taki rytualny performans nie jest już możliwy - przynajmniej na jego ślad? Cała ta sytuacja przywodzi na myśl odwrót Autentyczności opisany przez Benjamina w eseju o Dziele sztuki w dobie reprodukcji technicznej.

Scholem szuka więc sposobu, by zachować ślad świętego Imienia, a także ślad objawienia przyobiecanego i zapieczętowanego w tym Imieniu - choćby i było to objawienie nicości. O „nicości objawienia” pisze Scholem w korespondencyjnej dyskusji z Benjaminem poświęconej twórczości Franza Kafki. Stwierdza tu, że - w jego przekonaniu - Kafka potrafił odpowiedzieć na to wezwanie i stworzyć język czy tekst, który zachowuje ów ślad objawienia jego rewers czy negatyw:

Świat Kafki to świat objawienia, oczywiście widzianego z perspektywy, z której powraca ono do swej nicości. Fakt, że to, co objawione, jest niemożliwe do spetnienia, to punkt, w którym właściwie pojęta teologia (jak ją postrzegam ja, pogrążony w swojej kabale) jak najdokładniej zbiega się z ideą, stanowiącą klucz do świata Kafki [...]. Problemem, drogi Walterze, nie jest nieobecność objawienia w preanimistycznym świecie, lecz fakt, że nie można go wypetnić. [...] Uczniowie, o których piszesz na końcu eseju, to nie tyle tacy, co zgubili swoje Pismo [...], ile raczej tacy, co nie mogą go rozszyfrować. ${ }^{25}$

24 Tamże. 
Scholem wyobraża sobie zatem język, w którym - dokładnie tak jak tekst oryginalny w palimpseście - skrywa się Imię, potencjał objawienia. Podobnie jednak jak uczniowie nie mogą rozszyfrować swego Pisma, tak też owo Imię pozostaje nieczytelne. Niczym w palimpseście, w którym źródłowy tekst pozostaje obecny jako podłoże dla tekstu użytkowego, sam jednak jest nieczytelny, pozbawiony znaczenia, w opisywanym przez Scholema stanie objawienie zachowuje „jeszcze swoją pozycję, obowiązuje, lecz nic nie znaczy”:

Pytasz, co rozumiem, przez „nicość objawienia”? [...] [To stan, w którym - przyp. A.L.] zanika bogactwo znaczeń, a to, co się zjawia (objawienie jest bowiem czymś, co się zjawia), zostaje zredukowane do zerowego poziomu swojej treści, lecz mimo to nie znika. Dla religii jest to, rzecz jasna, przypadek graniczny i należy mocno wątpić, czy naprawdę może dojść do czegoś takiego. Nie mogę się z Tobą zgodzić, że to wszystko jedno, czy uczniowie zgubili „Pismo”, czy też nie mogą go rozszyfrować. Jest to, moim zdaniem, jeden z najpoważniejszych błędów, jakie mogłeś popełnić. Mówiąc o nicości objawienia, chcę właśnie uchwycić różnicę między tymi dwoma stanami. ${ }^{26}$

Według Sary Dillon przywołanie metafory palimpsestu w rozważaniach nad odwróconą czy negatywną teologią wymaga deformacji rzeczywistego, fizycznego fenomenu palimpsestu, a także sposobu, w jaki metafory tej używano w dawniejszej krytyce literackiej, ponieważ w „odczytaniu palimpsestowym (palimpsestuous) żadna warstwa tekstu nie stanowi zasadniczej czy definitywnej wersji dzieła" ${ }^{27}$. Zgodnie z tym rozumowaniem, teza, że wyjściowy, wymazany tekst jest tekstem „zasadniczym”, „prawdziwym” czy źródłowym, z którego wywodzą się inne, oznacza zagubienie jednej z najciekawszych cech idei palimpsestu: cechą tą jest przygodność nadpisywanych tekstów i brak relacji pierwszeństwa czy źródłowości między nimi. Postawienie takiej tezy oznacza zatem poniekąd zawłaszczenie metafory, która jest szczególnie przydatna dla poststrukturalistycznej krytyki literackiej i koncepcji języka, i wpisanie jej na powrót w ramy neoromantycznej, dualistycznej koncepcji języka. A jednak to właśnie chiałabym zrobić w niniejszej analizie.

26 Tamże, s. 292.

27 S. Dillon The Palimpsest, s. 47. Jeśli chodzi o cytat wewnętrzny por. J. Derrida Biała mitologia, przeł. J. Margański, w: tegoż Marginesy filozofii, przeł. A. Dziadek, J. Margański, P. Pieniążek, KR, Warszawa 2002, s. 317. 
Dillon pisze:

Jeden tekst nie wywodzi się z drugiego, jeden nie służy jako źródło drugiego - palimpsest nie stanowi adekwatnej figury relacji między tekstem a jego źródłami, włączając w to jego wcześniejsze wersje. Gdy zatem posługujemy się figurą palimpsestu w odniesieniu do relacji wyłonienia i reakcji zachodzącej między warstwami palimpsestu, decydujemy się na katechrestyczne użycie tej metafory, czyli - zgodnie z definicją The Oxford English Dictionary - „wykoślawione, niewłaściwe użycie słowa”. [...] W ujęciu Jacques'a Derridy, katechreza to „inwazyjna, wymuszona, gwałtowna inskrypcja znaku, narzucenie znakowi pewnego sensu, który nie doczekał się jeszcze własnego znaku w języku".28

Prócz tego, że w kontekście rozważań nad otchłanną naturą języka obraz palimpsestu wydaje się nader pociągający, warto również uwypuklić ów aspekt przemocy: filozoficzny gest Scholema, Benjamina i innych myślicieli piszących w trzecim języku polega właśnie na gwałtownej inskrypcji neoromantycznej tęsknoty za bożym Imieniem, na wpisaniu jej w obręb pewnej formy - języka - który uwolnił się od teologii. Także pisarstwo Derridy zachowuje więcej niż tylko nostalgię za bożym Imieniem. Tego rodzaju pisanie stara się przede wszystkim przemycić ślad mesjańskich przeczuć do postteologicznego świata. Można by zapytać: czy wiara nie jest zawsze pewnym aktem przemocy wobec rozumu? Czyż objawienie nie jest rodzajem eksplozji lub destrukcji dotychczasowych kategorii, czy wręcz rozerwaniem, rozcięciem dziejów? Tekst palimpsestowy ma właśnie sprawić, by tego rodzaju fluktuacja stała się możliwa - by otchłań wdarła się w obręb codzienności.

Ten aspekt przemocy jest bodaj szczególnie dobitnie uwypuklony w tekście Scholema, który postrzega nawrót, przebudzenie bożego Imienia w obrębie języka codziennego jako wydarzenie destrukcyjne, apokaliptyczne, jako bożą pomstę:

Czyż otchłań świętego języka, który wpajany jest naszym dzieciom, nie musi ponownie się rozewrzeć? [...] Czy religijna moc tego języka nie musi któregoś dnia wybuchnąć i uderzyć w tych, którzy nim mówią? I które pokolenie doświadczy tej eksplozji? [...] A nikt nie wie, czy ofiara tych,

28 Tamże. 
którzy zginą w tej otchłani, będzie wystarczająca, by ją zasklepić. [...] Ta hebrajszczyzna brzemienna jest nieszczęściem. ${ }^{29}$

Idea gwałtownego wtargnięcia świętości w obręb świata codziennego rzadko przybiera postać tak otwartej groźby w innych pismach tej tradycji. Zwykle pozostaje ona na poziomie teoretycznym i traktowana jest jako aspekt percepcji filozoficznej lub artystycznej. Dla Waltera Benjamina inwazja Imienia to coś, co ma wydarzyć się całkowicie poza czasem historycznym, coś, co rozerwie historię i uczyni ją nieistotną. W naznaczonych mesjańskim duchem tezach $O$ pojęciu historii, które z pewnością można określić mianem tekstu pisanego w trzecim języku, materialista historyczny porusza się w teraźniejszości, pozostawia jednak otwarte drzwi, bardziej chyba pragnąc ucieczki, niż się jej obawiając: Benjamin kończy swój ostatni tekst spostrzeżeniem, że dla Żydów każda sekunda „była małą furtką, przez którą mógł wkroczyć Mesjasz" $^{\text {"30 }}$. Z kolei dla Derridy obrazem, który wysuwa się na plan pierwszy, jest wizja nawiedzenia - nawiedzenia codzienności przez widmowe ślady tego, co boskie. Być może dlatego właśnie Derrida uległ fascynacji tekstem Scholema, w którym nawiedzenie staje się tropem zasadniczym. Jak pisze Elliot Wolfson, „mesjaniczność Derridy to doktryna «widmontologii», nawiedzającego «zjawiania się tego, co niezjawiskowe», które rozrywa ontologię"31.

Sądzę, że dla obu autorów ów zasadniczy trop nawiedzenia - nawiedzenia świeckiego języka przez „imiona”, słowa obarczone brzemieniem etycznej czy duchowej odpowiedzialności - staje się właściwym locus etycznego ładunku zawartego w ich tekstach. W liście Scholema czytamy:

Język to imię. W imieniu zamknięta jest potęga języka, opieczętowana jest jego otchłań. [...] My [...] mówimy językiem widmowym: w naszych wypowiedziach imiona błąkają się niczym duchy, w tekstach i gazetach ten czy ów igra nimi i okłamuje siebie lub Boga, że to nic nie znaczy, a z upiornego pohańbienia naszego języka tryska często moc tego, co święte. Imiona bowiem mają swoje życie, a gdyby go nie miały, biada naszym dzieciom, które bez żadnej nadziei wydane będą pustce. ${ }^{32}$

29 G. Scholem Wyznanie o naszym języku, s. 329-331. W. Benjamin O pojęciu historii, w: tegoż Konstelacje, s. 323. E.R. Wolfson Assaulting the Border: Kabbalistic Traces in the Margins of Derrida, ") ournal of the American Academy of Religion" 2002 70(3), s. 482. 
O ile Scholem mówi tu o odpowiedzialności w sposób bezpośredni - nawet jeśli za pomocą mowy symbolicznej - Derrida odtwarza fenomen nawiedzenia w ramach własnego eseju jako pewną strategię literacką. Dekonstruując list Scholema, wydobywa zeń przesłankę, którą pragnie ocalić: ideę nawiedzonej natury języka. Podejmując „jak najbardziej wewnątrztekstową" lekturę tego listu, poddaje go nader subtelnej operacji. W kilku zasadniczych punktach swojej analizy przywołuje nazwiska innych filozofów, pozwalając im wtargnąć w obręb tego odczytania. Nazwiska te nie zostały oczywiście wybrane arbitralnie; w miejscach, gdzie zostają wspomniane, wprowadzają do tekstu złowróżbny wydźwięk. I tak np. pod koniec tekstu Derrida podejmuje kwestię ofiary ze świętego języka - mordu na nim, o którym mowa w tekście Scholema. Derrida pisze:

Nieuchronna ofiara, jednocześnie miniona i niemożliwa, ukazuje, a raczej zapowiada święty język jako taki, należącą do języka sakralność. Zgodnie z logika, która nieprzypadkowo przypomina Was ist Metaphysik Heideggera i dotyczy całości bycia w jego relacji do słowa, nicość - tutaj nicość języka, nie-język - zapowiada istotę tego, czemu zagraża i co w całości usuwa. ${ }^{33}$

Derrida nie rozwija w tym miejscu wzmianki o Heideggerze, pozwala jednak, by jego nazwisko pojawiło się w szczelinie tekstu Scholema, w tym nazwisku zaś - imieniu - istotnie zapieczętowane są złowróżbne skojarzenia z nacjonalizmem, które zarówno język Scholema, jak i naszą lekturę jego tekstu obarczają brzemieniem odpowiedzialności. Nie rozwodząc się nad konsekwencjami swojego spostrzeżenia, Derrida zdaje się podpisywać pod tezą Scholema, zgodnie z którą same imiona zawierają moc przymierza i odpowiedzialności. Wydaje się niemal, że igra on tutaj z symboliczna funkcją języka przywoływaną w tekście Scholema, pozwalając, by przedostała się do jego logicznej krytyki.

Na późniejszym etapie Derrida rozważa kwestię sekularyzacji w tekście Scholema - tej właśnie sekularyzacji, do której zdaniem Scholema dojść nie może i która jest jedynie façon de parler. Okoliczność, że Scholem posługuje się francuskim wyrażeniem, staje się dla Derridy punktem wyjścia do tego, by ponownie podjąć kwestię nacjonalizmu i esencjalizacji Geist, ducha narodowego w filozofii niemieckiej. Sięgając po chytry zabieg retoryczny, uwypukla pewne nazwisko - imię - właśnie przez to, że go nie wymawia, a tym samym 
podwaja jego widmową moc: „Oto co pisze przyjaciel i miłośnik Mendelssohna" - i w tym miejscu Derrida przytacza długi przypis z tekstu Kanta, „w całości zainspirowany najpospolitszym antysemityzmem”. Tak się zaś składa - okoliczność to nader fortunna dla Derridiańskiej gry z ideą imienia, które nawiedza język - że w swoim przypisie Kant określa Żydów mianem „Palestyńczyków”34.

W innym miejscu Derrida kilkakrotnie posługuje się cudzysłowem w taki sposób, że wydobywa jakąś frazę z tekstu Scholema i kojarzy ją z innymi widmowymi imionami, które wcześniej wprowadził. I tak cytuje fragment z listu Scholema: „czy wówczas będziemy mieli młodzież zdolną stawić czoło buntowi świętego języka?" ${ }^{35}$, by następnie - izolując określenie czy imię „nasza młodzież" - wydobyć na plan pierwszy obecne w tekście Scholema widmo nacjonalizmu: „nie wiemy, w roku 1926, jaka odpowiedzialność spadnie na «naszą młodzież» w obliczu tego gwałtownego powstania, niepowstrzymanego powrotu sacrum. Czy młodzież ta zostanie zmiażdżona czy też okaże się godna tego dziedzictwa?" Derrida nie stara się ukryć sarkastycznego tonu. „Można do woli dywagować,” pisze, „spekulować na temat konkretnej postaci, jaką przyjmowała ta możliwość w sumieniu Scholema, a także na temat jej podobieństwa do tego, czym się faktycznie stała, czym stała się ówczesna młodzież - na przykład dzisiejszym narodem izraelskim"36.

W istocie możemy dostrzec, że zasadnicza strategia Derridy polega na tym, by skonfrontować nas z wewnątrztekstową lekturą listu Scholema - a ów list sam stara się pozostać we wnętrzu żydowskiej, dokładniej zaś kabalistycznej tradycji tekstualnej, czy też do wnętrza tej tradycji powrócić - z lekturą wszelako, która jest nieustannie nawiedzana przez „imiona” czy znaczące nasycone ostrzeżeniami przed nacjonalizmem i faszyzmem, ideologiami sprzymierzonymi z esencjalizującym użyciem języka. Derrida nakłania nas do tego, byśmy zastanowili się nad mocą, która została zapięczętowana w tych słowach czy imionach. To właśnie owo brzemię odpowiedzialności naznacza jego tekst i - jak się zdaje - motywuje jego odczytanie listu Scholema. Z punktu widzenia Derridy teksty takie jak ów list - swoiste ćwiczenie z nowoczesnego pisarstwa mesjańskiego, które nie uniwersalizuje swego rozumienia mistycznego rozumienia języka ani też, inaczej niż

\footnotetext{
34 Tamże, s. 363.

35 G. Scholem Wyznanie o naszym języku, s. 330.

36 J. Derrida Oczy języka, s. 354.
} 
teksty Benjamina, nie zrywa więzów z politycznie nacechowanym kontekstem przedsięwzięcia syjonistycznego - a zatem tego rodzaju teksty paradoksalnie przyczyniają się do tego, czego się obawiają: do powrotu potęgi (a może być to potęga stłumionych uczuć religijnych społeczeństwa), która skrywa się w sakralnych formach i imionach - do jej powrotu w mściwej postaci, w której potęga ta zwraca się przeciw użytkownikom języka. Derrida wskazuje, że posługując się takim, a nie innym językiem, Scholem tworzy tekst, który można wykorzystać zarówno do celów bałwochwalczych, jak i ikonoklastycznych.

W finale eseju Derrida wykracza poza szczegółowe odczytanie listu Scholema i dodaje komentarz utrzymany w innej tonacji, w którym bardziej bezpośrednio stawia kwestię odpowiedzialności. Najpierw przytacza długi cytat zaczerpnięty z interpretacji listu Scholema zaproponowanej przez francuskiego uczonego, Stéphane'a Mosèsa, następnie zaś stawia pytanie - nominalnie w odniesieniu do tej właśnie interpretacji:

W jakim stopniu wyjaśnienie z grubsza rzecz biorąc psychoanalityczne, psychoanalityczno-historyczne, a więc naukowe, zależne od współczesnego racjonalizmu, od nowego określenia historycznej podmiotowości związanej z teorią znaku, a zatem wyjaśnienie w zasadzie niedopuszczalne dla aksjomatyki tego wyznania pozwala wyostrzyć paradoks, w którym - jak byłbym skłonny twierdzić, może zbyt pochopnie - dziś żyjemy? $\mathrm{Na}$ czym polega ten paradoks? Czy myśl o języku, doświadczenie języka pozwalające zdekonstruować filozoficzne opozycje panujące w semiotyzmie odziedziczonym po platonizmie i oświeceniu może - proponując krytykę krytyki i wykraczając poza wyznaczone granice pewnego typu naukowości - narażać się na naukowe, filozoficzne i polityczne ryzyko odrzucenia nauki, filozofii, nie wspominając o ryzyku nacjonalistycznym? ${ }^{37}$

W tym właśnie punkcie wywodu niespodziewanie odnajdujemy moment aprobaty dla tekstu Scholema - tekstu, któremu wcześniej nieraz się od Derridy obrywało. Oto bowiem sam Derrida pozwala sobie na ton przestrogi i wskazuje niebezpieczeństwo, do jakiego mógłby prowadzić niewłaściwy użytek czyniony z języka. Tym samym zaś przyjmuje rdzeń argumentacji Scholema, nawet jeśli wyraziście odgradza się od niego pod względem politycznym. 
W niniejszych rozważaniach metafora palimpsestu miała dopomóc w uchwyceniu sposobu, w jaki teksty Scholema i Derridy odnoszą się do kwestii natury języka. Oba eseje przyjmują perspektywę, z której - przynajmniej na poziomie pojęciowym - język święty i język świecki jawią się niczym dwa teksty, nałożone jeden na drugi, a interakcja między tymi warstwami staje się siłą napędową tego typu pisania o języku, a zarazem właściwym tematem obu tekstów. Palimpsestowa koncepcja języka służy też w obu tych esejach jako metonimia stosunków panujących w kontekstach społeczno-politycznych, z których prace te wyrastają. Oba teksty dotyczą mianowicie relacji między wyzwaniami pewnej konkretnej sytuacji politycznej a teologicznymi czy postteologicznymi kwestiami dotyczącymi natury języka, a także relacji między językiem i działaniem etycznym. W tej drugiej wersji palimpsestowej metafory polityczne i historyczne okoliczności, które leżą u źródeł obu esejów, tworzą jedną z warstw tekstu, a zarazem tło dla analiz natury języka, podejmowanych w duchu współczesnych ujęć teologii negatywnej. Dla Scholema kontekstem politycznym jest kwestia syjonistyczna w stadium początkowym: wyzwania związane z utworzeniem państwa żydowskiego i negocjacją politycznych, społecznych i duchowych stosunków z tradycją. W eseju Derridy wyzwania zrodzone przez kwestię syjonistyczną pozostają nierozwiązane, a w kontekście konfliktu izraelsko-palestyńskiego stają się szczególnie palące pod względem moralnym. Esej Oczy języka został pierwotnie wygłoszony jako wykład w roku 1985, podczas pierwszej wizyty Derridy w Izraelu, na krótko przed wybuchem palestyńskiego powstania ${ }^{38}$.

Być może więc najpłodniejszym aspektem metafory palimpsestu odniesionej do lektury obu tych esejów jest aspekt nawiedzenia, który metafora ta wydobywa na plan pierwszy. Idzie o sposób, w jaki tradycja - zwłaszcza zaś zasady teologiczne oraz generowane i wspierane przez nie ideologie nawiedzają nasze myślenie i działanie we współczesnych okolicznościach historycznych. Palimpsest, który zgłębiają teksty pisane w trzecim języku, to splot relacji między polityką i teologią. Teksty te domagają się przede wszystkim koncentracji na etycznym brzemieniu ciążącym na jednostce, która żyje w języku i w tym właśnie języku, w palipsestowym, migotliwym żywiole między świętym i świeckim, na krawędzi otchłani, musi wypracować koncepcję należytego działania.

38 Zob. J. Powell Jacques Derrida: A Biography, Continuum, London-New York 2006, s. 157. 
Dla Derridy ów tekst czy dyskurs naznaczony jest „mesjanicznością bez mesjanizmu": to cecha, etos czy postać pragnienia, które wpisane są nawet w dyskurs dekonstrukcji. W Widmach Marksa czytamy:

A tym właśnie, co pozostaje nieredukowalne do jakiejkolwiek dekonstrukcji, co pozostaje tak niedekonstruowalne, jak sama możliwość dekonstrukcji, jest być może pewne doświadczenie emancypacyjnej obietnicy; jest to być może sama formalność strukturalnego mesjanizmu, mesjanizm bez religii, a nawet mesjaniczność bez mesjanizmu, pewna idea sprawiedliwości - którą odróżniamy od prawa, a nawet od praw człowieka - i pewna idea demokracji - którą odróżniamy od jej aktualnego pojęcia i określających je dzisiaj predykatów. ${ }^{39}$

Jeśli Scholem przemyca do świata XX wieku teologiczne treści żydowskiego mesjanizmu, lokując je w kontekście dyskursu filologicznego, a wręcz pragnąc zachować w swoim pisaniu boską istotę języka hebrajskiego, Derrida postępuje krok dalej w procesie szyfrowania i przemyca to, co sakralne, do języka codziennego, sytuując ów sakralny moment w sferze profanum, w szczelinach otwierających się w mowie codziennego użytku. Parafrazując w Oczach języka stosunek Scholema do kategorii imienia, Derrida odsłania zarazem własne stanowisko: „Imię ukryte w swojej mocy posiada zdolność ukazywania i ukrywania, objawiania i szyfrowania"40,

Zarówno dla Scholema, jak i dla Derridy odwołanie do palipsestowej struktury języka - tj. przyjęcie zasadniczej przesłanki dotyczącej sakralno/ świeckiego, dwoistego charakteru języka i nawiedzenie naszej mowy przez Imię czy imiona - ma w istocie stanowić apel do czytelników, by dostrzegli etyczną odpowiedzialność, jaką tworzenie znaczeń nakłada na użytkowników języka. W tym sensie możemy myśleć o palimpseście jako o postteologicznej postaci przymierza. Palimpsestowe teksty Scholema i Derridy - tak jak mistyczne teksty Benjamina poświęcone naturze języka - odnawiają pewną obietnicę: mianowicie, że przestrzeń kontaktu z bożym Imieniem pozostanie otwarta.

39 J. Derrida Widma Marksa, przeł. T. Załuski, PWN, Warszawa 2016, s. 106.

40 J. Derrida Oczy języka, s. 356. 


\section{Abstract}

\section{Karen Underhill}

UNIVERSITY OF ILLINOIS AT CHICAGO

Writing in the Third Language: Between Sacred and Profane in Gershom Scholem and Jacques Derrida

This article explores Gershom Scholem's 'On Our Language: A Confession' (an open letter to Franz Rosenzweig on the secularisation of the Hebrew language) as well as Jacques Derrida's essay on Scholem's text. Underhill draws on the figure of the palimpsest and the cabbalistic concept of language in her attempt to reconstruct both texts. She also borrows Derrida's notion of the'third language' on the border between sacred and profane language.

\section{Keywords}

Jacques Derrida, Gershom Scholem, sacred language, secularisation, palimpsest 